\title{
A REVIEW ON DRUG NIMBUKA AS ANTIBACTERIAL, ANTICANCEROUS AND ADJUNCTIVE FOR CHEMOTHERAPY
}

\author{
Dr. Naveena K S \\ Assistant Professor, \\ Rajiv College of Ayurveda, \\ Hassan
}

\author{
Dr. Shrinath M. Vaidya \\ Professor, \\ SDM College of Ayurveda, \\ Hassan
}

Article DOI: https://doi.org/10.36713/epra5758

\begin{abstract}
In present scenario Cancer contributes to highest mortality rate. According to the vital statistics of 2016, around 14 lakh deaths have occurred due to Cancer. Cancer is conditions were new growth and division of abnormal cell is going to happen.

Nimbuka is the drug explained in Ayurveda by Acharya Bhavaprakasha as Krimigna and Prakruti-sthapaka. Nimbuka is anti-cancerous and adjunctive for chemotherapy and Rasayana (as per the information obtained from cell line studies). Nimbuka belongs to Rutaceae family which itself is proved having the anti-cancer drug property.

KEY WORDS: Nimbuka, Anticancerous, Citrus medica, Citrus limon etc
\end{abstract}

\section{INTRODUCTION}

A new growth of cell and division of cell abnormally occurs in cancer condition.

Nimbuka (Citrus limon) which is explained in Ayurveda classics, is a fruit as well as a vegetable used in day today life which is commonly known as "Acid lime of India". According to the data obtained from the Institute of health science - Baltimore, it is found that Citrus limonis having the Anti-Microbial Spectrum activity and acts as a barrier for the Bacteria and fungus effect over cancer ${ }^{1}$.

\section{REVIEW OF LITERATURE}

In Amradi-varga of BhavaPrakasha ${ }^{2}$, it is explained that Nimbuka destroys all types of krimi (including Parasites) choleric diarrhoea, vomiting and colic pain. It has the action of ama-pachana (Product of improper digestion and metabolism), shula (Colic pain), abdominal disorders ${ }^{3-4}$. It is used daily as nitya ahara dravya.

Ayurvedic properties of Nimbuka

\begin{tabular}{|c|c|c|c|}
\hline \multicolumn{2}{|c|}{ Sanskrit } & \multicolumn{2}{c|}{ English } \\
\hline Rasa & Amla & Taste & Sour \\
\hline Guna & Teekshna and laghu & Property & Sharp and light \\
\hline Virya & Ushna & Potency & Sour \\
\hline Vipaka & Amla & Metabolic property & \\
\hline
\end{tabular}

It helps to manage the adverse effects of chemotherapy like vomiting and diarrhoea and colic pain etc. It helps to correct Neutropenia (low white blood cell count in case of infection) and hence increase defence system as per the researches done and stated by Institute of Health Science, Boltimore ${ }^{1}$.

\section{CHEMICAL COMPOSITION}

1. Lemon Fruit juice $-7-10 \%$ citric acid
2. Phosphoric acid

3. Mallic acid

4. Citrate, Sugar, Mucin, Alkaloids, Hesperidin, Abscises acid

5. Alkaloids

6. Hesperidin

The leaves of Nimbuka - Contains Rectin, Hesperidin, neral, Geraniol, limonene, citral etc will be present. 


\section{PHARMACOLOGICAL ACTIVITIES}

1. Antimicrobial

2. Appetizer

3. Insecticidal

As per Research Profiles of recent scenario: 1) Antifungal activity: Leaf extract of Citrus limon was found to exhibit absolute fungi toxicity, showing broad antifungal spectrum 5 .

2) Antimicrobial activity. Leaf of Citrus limon is antimicrobial. It contains

a) Ocimene-17.1,

b) Linalool - 11.4,

c) Citral B $-49.3 \% 0^{6}$.

3) Antibacterial and Anticancerous activity: The Essential oils prepared out of leaves and stem of Citrus medica variety of limonum contains Limonene $32.4 \%$, beta - ocimene $7.3 \%{ }^{7}$

4) Rutin and Hesperidin : Have been isolated from the leaves of citrus limon ${ }^{8}$.

\section{DISCUSSION}

Nimbuka (Citrus limon) is explained as Krimighna, in Bhavaprakasha (an ancient text on Indian medicine). It also has vata-kapha-hara property by which it prevents progression of pathogenesis in conditions like arbuda, granthi, tridoshaja-gulma which are having similar nature of manifestation like cancer, mentioned in Ayurveda.

Krimighna action can be correlated to anti bacterial and antimicrobial activity. Vata-kapha-hara karma governs uncontrolled division of newly growing abnormal cells in the pathogenesis of cancer and also in stage of metastasis.

Nimbuka helps to prevent adverse effects of chemotherapy. Also destroys the carcinogenic cells without affecting the healthy cells. It controls the stress, colic pain, vomiting and diarrhoea which are caused immediately before and after chemotherapy. Also controls Neutropenia and brings back normal functioning of defence system.

According to Research database, since 1970 more than 20 experiments are conducted, among which 12 types are from cell line studies. It states that lemon is most safe (and effective than Adriamycin, commonly used chemotherapy medicine). It also slows down the aggregation and rapid development of cells in cancer. ${ }^{1}$

Leaves of citrus also play an important role in Antimicrobial activity.

\section{CONCLUSION}

Nimbuka is an easily available drug as well as nitya-ahara-upayogi-dravya having its contribution in treating cancer. According to Baltimore institute of health sciences, not only lemon juice but also its Leaf extracts have anti microbial and antifungal effect in condition of cancer.

Ayurveda also says that, nimbuka acts as krimighna, chardi-nigrahana (anti emetic) and agnideepaka (appetizer). Lemon juice when administered appropriately is effective in tridoshavaishamya, agnimandya, vatavyadhi, baddhaguda and visuchika.

Lemon, a commonly used drug is useful in simple ailments like indigestion to complex stages of cancer. The spectrum of uses of Citrus limon has to be explored, experimented and documented and widely used.

\section{REFERENCES}

1. Institute of health sciences, Baltimore University 819 NLLC, Charles street, Baltimore, MD12DL

2. Vaisya rupulal, Vidyotini on BhavaPrakasha Nighantu of Bhavamishra, $9^{\text {th }}$ ed.,published by choukambha Sanskrit sansthan, Varanasi,1999, Amradi Varga, Veres no 37 \& 38 p.595

3. AP Plant Drugs - https://books.google.co.in

4. Indian material medica https://books.google.co.in

5. Dube NK etal,1982, India J Bot,5(1),20-22; Indian per fum 1981;25(3-4),1-3

6. Indian J Pharma 1976, 38, 159

7. J Agri Food Chem, 1981, 29,490

8. MAPA, CSIR, Oct 1986, 2813,47 